\title{
Botanical Composition and In Situ Dry Matter Degradability of Legume- Grass Mixture Pasture Fertilized with Different Amounts of Nitrogen
}

\author{
Numan Kılıçalp ${ }^{1 *}$, Mustafa Avcı ${ }^{2}$ Hatice Hızlı ${ }^{3}$, Rüştü Hatipoğlu ${ }^{4}$, Tugay Ayaşan ${ }^{3}$ \\ ${ }^{1}$ Department of Animal Science, Agricultural Faculty, Gaziosmanpaşa University, 60240 Taşllçiftlik/Tokat, Turkey \\ ${ }^{2}$ Department of Crop Science, Faculty of Agricultural Science and Technologies, Ömer Halisdemir University, 51240 Niğde, Turkey \\ ${ }^{3}$ Department of Animal Science, East Mediterranean Agricultural Research Institute, O1220 Adana, Turkey \\ ${ }^{4}$ Department of Crop Science, Faculty of Agriculture, Çukurova University, 01330 Adana, Turkey.
}

\begin{tabular}{l}
\hline A R T I C L E I N F O \\
Research Article \\
Received 12 July 2017 \\
Accepted 04 December 2017 \\
\hline
\end{tabular}

Keywords:

Botanical composition

Dry matter degradability

In situ

Nitrogen fertilizer

Pasture

*Corresponding Author:

E-mail: numankilicalp@hotmail.com

\begin{abstract}
A B S T R A C T
This study was conducted to determine the effects of different nitrogen (N) fertilizer levels on botanical composition, dry matter (DM) yield, chemical composition, in situ ruminal DM and NDF degradability and net energy lactation (NEL) of a native legumegrass mixture pasture. Field and degradability trials were arranged in a Complete Randomized Block Design with three replicates. Pasture was fertilized at six levels of $\mathrm{N}$ fertilizer (ammonium nitrate, N0, N50, N100, N150, N200 and N250 kg/ha). Three rumen cannulated Holstein Friesian heifers (3-4 year old) were used. Feed samples were incubated for $0,8,12,24,36,48,72$ and $96 \mathrm{~h}$. Application of nitrogen fertilizer results indicated that nitrogen fertilizer decreased the legumes ratio (LR) of pasture, approximately $22.4 \%$, Although $\mathrm{N}$ fertilizer increased the grass ratio (GR) of pasture approximately 55.8\%. Dry matter (DM), Net energy lactation (NEL, Mcal/kg) and ash contents of pasture were increased by increasing $\mathrm{N}$ fertilizer level. However, when $\mathrm{N}$ fertilizer level increased acid detergent fiber (ADF) concentration of pasture decreased. Application of the different rate of nitrogen fertilizer had no effect on in situ rumen degradability of DM and NDF of pasture. It was also found that there was the significant positive relationship between effective NDF degradability at $48 \mathrm{~h}$. rumen incubation period and different level of $\mathrm{N}$ fertilizer. In addition, it was determined that there was a linear and quadratic positive relationship between DM yield and different nitrogen doses. In conclusion, different rates of nitrogen application changed botanical composition, decreased ADF content and increased NEL and effective rumen degradability of neutral detergent fiber (EDNDF 48 h.) of pasture.
\end{abstract}

DOI: https://doi.org/10.24925/turjaf.v6i1.16-21.1413

\section{Introduction}

Native pasture originates mostly grass and legumes which are the main source of herbage for feeding ruminants. Therefore, pasture must be managed correctly to increase the herbage quality. One of the important management practise and topic in intercropping systems is nitrogen fertilizer. Some research results have shown that nitrogen fertilizer positively affects the grasses, on the other hand, negatively affects the legumes in intercropping systems (Acikgöz, 2001). Naturally grown grass species give the high quality herbage by applying of $\mathrm{N}$ fertilizer (Khan et al., 1999). Farmers want to produce the more quality forage from grassland for their animals. Therefore, $\mathrm{N}$ fertilizer is used on grassland for contributing to the pasture productivity in terms of forage yield and quality. Increasing of the amount of nitrogen fertilizer applications decreased ADF and NDF concentration of rye grass (Zhang et al., 1995). So that, nutritive value of grassland can be increased with increasing levels of nitrogen application (Valk et al., 2000). Besides, same researchers reported that increasing nitrogen fertilizer enhanced the grass rate, ruminal DM degradability of grass and herbage yield of grass- legume pasture. On the other hand, nitrogen fertilizer decreases legume ratio and NDF content of grass- legume pasture (Arvas et al., 2011). Bleanger et al. (1998) pointed out that nitrogen deficiency reduces in vitro true DM and cell wall digestibilities. Besides, nitrogen fertilizer increased DM digestibility of some tropical grasses by $9 \%$ (Carver et al., 1975). Forage quality in terms of chemical composition, ruminal DM degradation characteristics and 
ME are big indicators for feed evaluation. These effects of fertilizer on animal feed intake and animal productivity by converting plant material to animal tissue are important for animal feeding (Zimmerman, 1980). Some important features of cell-wall structure and development may be related to degradability of the cell wall by ruminal microorganisms (Jung and Allen, 1995). Recently, researchers have shown that nitrogen fertilizer application is beneficial to production in terms of DM digestibility. Little information on fertilizer management of native legume- grass mixtures is available (Dong et al., 2005).

The hypothesis tested in this study was that application of nitrogen on pasture would significantly change botanical composition, chemical composition, in situ ruminal dry matter degradability characteristics and NEL content of a native grass-legume mixture pasture.

\section{Materials and Methods}

\section{Location and Climate Condition}

The trial was conducted in a native grass-legume mixture pasture in Ceyhan, Adana, Turkey in 2010 during the growing season. Experimental area was estabilished at latitude and longitude $37^{\circ} 00^{\prime} 64^{\prime \prime} \mathrm{N}$ and $35^{\circ} 44^{\prime} 87^{\prime \prime} \mathrm{E}$, altitude is $100 \mathrm{~m}$ above sea level. The soil of the experimental area was slightly salty and clay. The enviromental conditions and dates were collected from the meteorological service of Turkish state. During the growing period, average temperature and annual precipitation of experimental area were $13.9^{\circ} \mathrm{C}$ and 629.9 $\mathrm{mm}$.

\section{Agronomic Practices}

At the beginning of this trial, experimental area contained the high percentage of legume species as Trifolium fragiferum, Trifolium nigrescens, Trifolium lappaceum, Medicago hispida, Medicago orbicularis and Scorpirus subvillosus and as grasses Hordeum bulbosum, Lollium italicum, Koeleria phloides, Alopecirus myososroides, Phalaris canariensis and Polypogon mospeliensis. Six levels of N fertilizer (N0, N50, N100, $\mathrm{N} 150, \mathrm{~N} 200$ and $\mathrm{N} 250 \mathrm{~kg} / \mathrm{ha}$ as ammonium nitrate) were applied in $4 \mathrm{~m} \times 20 \mathrm{~m}$ plots and replicated three times with complete randomized block design. After harvested herbage sample taken from pasture was separated by hand as grass, legume and other species in order to determine botanical composition. On the other hand, the ratio of other species was very lower than grass and legume plants in the pasture.

\section{Sample Preparation}

Forage samples were collected with a harvester at $50 \%$ flowering stage of plants from the each plot. An area of $1 \mathrm{~m}^{2}$ was hand clipped from each of the 3 replicated plots for estimation of forage production. The forage samples of each treatment were taken as three replicates and then herbage samples were brought to the laboratory. Samples were dried at $70^{\circ} \mathrm{C}$ for $48 \mathrm{~h}$. and ground in mill 1 $\mathrm{mm}$ for chemical analysis and $2.5 \mathrm{~mm}$ screen for in situ DM degradability analysis. Dry matter content of forage samples was determined by drying at $105^{\circ} \mathrm{C}$ over night then their ash content was determined by burning the samples in muffle furnace at $525^{\circ} \mathrm{C}$ for $8 \mathrm{~h}$. (AOAC,
1990). Additionally, ADF and NDF contents of forage samples were determined (Van Soest et al., 1991) by using ANKOM Fiber Analyzer (F220/220 Operator's Manual, Ankom tech.).

\section{In Situ Incubations}

Holstein Friesian heifers (3-4-year-old) were cannulated with large rumen cannula $(10 \mathrm{~cm}$ internal diameter; Diamond Inc.). Heifers with an average body weight (BW) of $450 \pm 30 \mathrm{~kg}$, were used to evaluate forages by using in situ nylon bag method. Besides heifers were housed in individual pens and allowed to adapt to the experimental conditions during the 3 weeks period. Animals were fed on alfalfa $(70 \%)$ and grass forage $(30 \%)$ based diet as recommended by NRC (2001) and mineral supplement (One kilogram of premix contains the following: $400 \mathrm{~g}$ limestone, $100 \mathrm{~g}$ Calcium perphosphate, $200 \mathrm{~g}$ salt, $\mathrm{MgO} 90 \mathrm{~g}$, Vit A 320.000 IU, Vit D 75.000 IU, Vit E $165 \mathrm{mg} / \mathrm{kg}, \mathrm{Fe}, 1.500 \mathrm{mg}$, Cu $685 \mathrm{mg}, \mathrm{Zn} 2.500 \mathrm{mg}$, Mn $1.500 \mathrm{mg}$, Se $80 \mathrm{mg}$, I30 mg, Co $25 \mathrm{mg}$ ), salt and free access to fresh water twice daily in equal portions at 08.30 and $16.30 \mathrm{~h}$. The herbage samples taken from the pasture were dried and ground to $2.5 \mathrm{~mm}$ screen then, $5 \mathrm{~g}$ subsamples were transfered to nylon bags. (bag made of polyester and $7.5 \mathrm{~cm} \times 15.5 \mathrm{~cm}, 40$ micron pore size, Bar Diamond Inc.). Nylon bags were put into the rumen for incubations of $0,24,36,48,72$ and $96 \mathrm{~h}$. Heifers was used as block in complete randomized block design and the experimental groups was three replicates. After incubation, the samples were withdrawn from the rumen and bags were washed in cold water. Zero time disappearances was obtained by washing unincubated bags in similar fashion, and then bags were dried at $55^{\circ} \mathrm{C}$ in an oven for 48 hours (Lai and Thu Huong, 1999). In situ rumen DM degradability for each incubation period was calculated by using the equation below,

DM degradability $(\mathrm{DM}, \mathrm{g} / \mathrm{kg})=($ Inital weight - final weight) / (Inital weight $) \times 100$.

Degradation characteristics of DM were calculated by the equation given by Ørskov and McDonald (1979) below,

$$
\begin{aligned}
& \mathrm{D}=\mathrm{a}+\mathrm{b}\left(1-\mathrm{e}^{-\mathrm{ct}}\right), \\
& \begin{array}{l}
\text { Where; } \\
\mathrm{D} \quad=\text { the actual degradation after " } \mathrm{t} \text { " hours, } \\
\mathrm{a} \quad=\text { the portion of DM solubilized at the beginning } \\
\text { of incubation (zero time), } \\
\mathrm{b} \quad=\text { slowly degraded portion of DM in the rumen, } \\
\mathrm{c} \quad=\text { rate constant for the degradation of " } \mathrm{b} \text { ", } \\
\mathrm{t} \quad=\text { time of incubation. }
\end{array}
\end{aligned}
$$

Degradation characteristics; a, b, c and effective ruminal degradability of DM was calculated by Ørskov and McDonald (1979).

The effective dry matter and NDF degradability were calculated by using equation,

$$
\mathrm{ED}=\mathrm{a}+(\mathrm{bc} / \mathrm{c}+\mathrm{k})
$$

Where:

$\mathrm{k}=$ ruminial out flow rate, $\mathrm{k}_{1}=0.02 / \mathrm{h}, \mathrm{k}_{2}=0.05 / \mathrm{h}$, for dry matter and NDF. 
The $\mathrm{NEL}_{(\mathrm{Mcal} / \mathrm{kg})}$ was calculated by the equation given by NRC, (2001)

$$
\mathrm{NEL}, \mathrm{Mcal} / \mathrm{kg}=2.149-(0.0223 \times \mathrm{ADF})
$$

\section{Statistical Analysis}

Data were calculated by the general linear model procedures (SPSS, 2007) as a completely randomized design with heifers as block. One-way analysis of variance (ANOVA) was used to determine the effects of $\mathrm{N}$ fertilizer on the chemical composition, NEL Mcal/kg and rumen degradation characteristics of forage samples. Significance between the treatments means was identified using Duncan multiple range test. Prediction equations for effective degradability (ED) and forage yield based on chemical composition were calculated by linear and quadratic multiple regressions.

\section{Results}

Botanical composition of pasture was significantly changed after application of $\mathrm{N}$ fertilizer. Legume and grass rates of pasture were summarized in Table 1. Although nitrogen application from 0 to $250 \mathrm{~kg}$ per hectare steadily decreased ratio of legumes from 85 to $66 \%, \mathrm{~N}$ application increased grass ratio of pasture from 15 to $34 \%(\mathrm{P}<0.05)$. DM yield of pasture was presented in Table 1. Dry matter yield of pasture ranged from 5592 to $7195 \mathrm{~kg} / \mathrm{ha}$, the lowest and the higest forage yield was obtained from control and N200 application groups respectively. But, there was no significant difference between different rates of $\mathrm{N}$ fertilizer applications. In contrast, $\mathrm{N}$ application on pasture significantly increased DM content of pasture from 90.4 to $92.1 \%$, respectively. Likewise, ADF content of pasture was significantly decreased with increasing $\mathrm{N}$ application $(\mathrm{P}<0.01)$.

NEL values of pasture were seen in Table 2. Application of $\mathrm{N}$ fertilizer significantly increased $\mathrm{NEL}_{(\mathrm{Mcal} / \mathrm{kg})}$ content of pasture $(\mathrm{P}<0.01)$. The highest NEL values were obtained from $150 \mathrm{~kg} / \mathrm{ha}$ and $250 \mathrm{~kg} / \mathrm{ha}$ nitrogen application groups

Ash content of pasture herbage was increased up to $4.3 \%$ with increasing the level of nitrogen from 0 to 250 , except on N50 group. Besides, NDF content of grassclover mixed swards ranged from 56.3 to $58.5 \%$, was not significantly affected by $\mathrm{N}$ treatments (Table 2 ).

Ruminal DM and NDF degradability and ruminal degradation characteristics of pasture were summarized in Table 3 and in Figure 1. Nitrogen fertilizer application did not changed DM and NDF degradability and ruminal degradation characteristics of native pasture for other rumen incubation times. However, the effective rumen degradability of NDF of pasture was significantly affected in $48 \mathrm{~h}$ period of rumen incubation. As shown in Table 3.

The equations for prediction of forage yield and ED by using multiple regression were given in Table 4 and Relationship between ADF content and grass ratio was shown in Figure 2. As shown on regression equation, the forage yield was increased by increasing rate of nitrogen fertilizer. As a result, there was a significant linear and quadratic positive relationship between forage yield and application of nitrogen fertilizer on pasture $\left(\mathrm{P}<0.05, \mathrm{R}^{2}\right.$ $=0.248$ ). As indicated in this equation (Forage yield $(\mathrm{kg} / \mathrm{ha})$ $=5846.048+5.946 \mathrm{~N}$ ), each kilogram of $\mathrm{N}$ increased in a 5.946 unite of forage yield.

The ADF concentration of the pasture was affected by ratio of legume and grass of the pasture. As illustrated in Figure 2 and Table 4, there was a strong positive relationship between legume ratio and $\mathrm{ADF}$ content of mixture swards. In contrast, there was a very significant negative relationship between grass ratio and ADF content of pasture in terms of pasture composition $\left(\mathrm{P}<0.01, \mathrm{R}^{2}=0.457\right)$. Besides, there was a significant linear and quadratic positive relationship between $\mathrm{N}$ application and effective rumen degradability of NDF at the $48 \mathrm{~h}$. rumen incubation period $\left(\mathrm{P}<0.05, \mathrm{R}^{2}=22 ; \mathrm{P}<0.05\right.$, $\left.\mathrm{R}^{2}=0.328\right)$.

Table 1 Botanical composition and dry matter yield of pasture

\begin{tabular}{|c|c|c|c|c|c|c|c|c|}
\hline \multirow{2}{*}{ Parameter } & \multicolumn{6}{|c|}{ Nitrogen fertilizer $(\mathrm{kg} / \mathrm{ha})$} & \multirow{2}{*}{ SEM } & \multirow{2}{*}{ Sig } \\
\hline & $\mathrm{HO}$ & $\mathrm{H} 50$ & $\mathrm{H} 100$ & H150 & $\mathrm{H} 200$ & $\mathrm{H} 250$ & & \\
\hline Legume ( \%) & $85.0^{\mathrm{a}}$ & $77.0^{\mathrm{abc}}$ & $80.0^{\mathrm{bc}}$ & $76.0^{\mathrm{abc}}$ & $67.0^{\mathrm{ab}}$ & $66.0^{\mathrm{c}}$ & 3.70 & $*$ \\
\hline Grass $(\%)$ & $15.0^{\mathrm{a}}$ & $23.0^{a b c}$ & $20.0^{\mathrm{ab}}$ & $24.0^{a b c}$ & $33.0^{\mathrm{bc}}$ & $34.0^{\mathrm{c}}$ & 3.70 & $*$ \\
\hline Forage yield (DM kg/ha) & 5592 & 6077 & 6709 & 7028 & 7195 & 6938 & 247.15 & ns \\
\hline
\end{tabular}

*Means with different subscripts within the same rows are significant $(\mathrm{P}<0.05)$; ns, Non significant; SEM, Standard error of mean

Table 2 Chemical composition of fertilized pasture

\begin{tabular}{|c|c|c|c|c|c|c|c|c|}
\hline \multirow{2}{*}{ Parameter \% } & \multicolumn{6}{|c|}{ Nitrogen fertilizer $(\mathrm{kg} / \mathrm{ha})$} & \multirow{2}{*}{ SEM } & \multirow{2}{*}{ Sig. } \\
\hline & N0 & $\mathrm{N} 50$ & N100 & N150 & N200 & $\mathrm{N} 250$ & & \\
\hline $\mathrm{DM}$ & $90.4^{\mathrm{a}}$ & $91.0^{\mathrm{ab}}$ & $92.4^{\mathrm{c}}$ & $91.7^{\mathrm{bc}}$ & $91.6^{\mathrm{bc}}$ & $92.1^{\mathrm{bc}}$ & 0.30 & $*$ \\
\hline NDF & 58.5 & 57.4 & 57.3 & 56.3 & 57.2 & 57.2 & 0.84 & ns \\
\hline $\mathrm{ADF}$ & $47.7^{\mathrm{c}}$ & $47.0^{\mathrm{c}}$ & $46.4^{b c}$ & $44.0^{\mathrm{a}}$ & $44.3^{\mathrm{ab}}$ & $44.0^{\mathrm{a}}$ & 0.58 & $* *$ \\
\hline Ash & $3.1^{\mathrm{ab}}$ & $2.5^{\mathrm{a}}$ & $2.7^{\mathrm{ab}}$ & $4.0^{b c}$ & $4.1^{b c}$ & $4.3^{c}$ & 0.64 & $*$ \\
\hline $\mathrm{NEL}_{(\mathrm{Mcal} / \mathrm{kg})}$ & $1.085^{\mathrm{c}}$ & $1.101^{\mathrm{c}}$ & $1.116^{b c}$ & $1.168^{\mathrm{a}}$ & $1.156^{\mathrm{ab}}$ & $1.168^{\mathrm{a}}$ & 0.0095 & $* *$ \\
\hline
\end{tabular}

DM, Dry matter; NDF, Neutral detergent fiber; ADF, Acid detergent fiber; Means within rows by different letters differ * $(\mathrm{P}<0.05)$, ** $(\mathrm{P}<0.01)$; ns, Non significant; SEM, Standard error of mean. 
Table 3 Ruminal degradation characteristics of fertilized pasture

\begin{tabular}{|c|c|c|c|c|c|c|c|c|}
\hline \multirow{2}{*}{ Item } & \multicolumn{6}{|c|}{ Nitrogen fertilizer ( kg/ha) } & \multirow{2}{*}{ SEM } & \multirow{2}{*}{ Sig. } \\
\hline & No & N50 & N100 & N150 & N200 & $\mathrm{N} 250$ & & \\
\hline \multicolumn{9}{|l|}{$\mathrm{DM},(\%)$} \\
\hline a & 30.16 & 28.52 & 29.33 & 31.26 & 29.76 & 27.27 & 0.80 & ns \\
\hline $\mathrm{b}$ & 38.70 & 39.08 & 39.88 & 40.10 & 40.46 & 42.11 & 2.16 & ns \\
\hline $\mathrm{a}+\mathrm{b}$ & 69.09 & 67.60 & 69.21 & 70.90 & 70.21 & 69.38 & 4.22 & ns \\
\hline $\mathrm{k}_{1(0.02 / \mathrm{h})}$ & 0.291 & 0.298 & 0.289 & 0.283 & 0.285 & 0.289 & 0.092 & ns \\
\hline $\mathrm{k}_{2(0.05 / \mathrm{h})}$ & 0.727 & 0.745 & 0.723 & 0.708 & 0.713 & 0.721 & 0.023 & ns \\
\hline $\mathrm{ED}_{1(\mathrm{k}=0.02 / \mathrm{h})}$ & 41.6 & 40.5 & 41.3 & 42.9 & 42.0 & 40.6 & 0.80 & ns \\
\hline $\mathrm{ED}_{2(\mathrm{k}=0.05 / \mathrm{h})}$ & 35.7 & 34.4 & 35.2 & 36.9 & 35.7 & 33.9 & 0.80 & $\mathrm{~ns}$ \\
\hline \multicolumn{9}{|l|}{$\mathrm{NDF},(\%)$} \\
\hline b & 27.75 & 24.67 & 21.76 & 22.65 & 23.22 & 19.07 & 2.98 & ns \\
\hline$a+b$ & -1.97 & -4.62 & -11.32 & -13.50 & -10.16 & -17.46 & 4.58 & $\mathrm{~ns}$ \\
\hline$c\left(h^{-1}\right)$ & 0.0069 & 0.0064 & 0.0054 & 0.0051 & 0.0056 & 0.0045 & 0.0005 & $\mathrm{~ns}$ \\
\hline $\mathrm{k}_{1(\mathrm{k}=0.02 / \mathrm{h})}$ & 0.349 & 0.373 & 0.365 & 0.341 & 0.356 & 0.362 & 0.115 & $\mathrm{~ns}$ \\
\hline $\mathrm{k}_{2(\mathrm{k}=0.05 / \mathrm{h})}$ & 0.871 & 0.931 & 0.913 & 0.852 & 0.889 & 0.903 & 0.265 & ns \\
\hline $\mathrm{ED}_{1(\mathrm{k}=0.02 / \mathrm{h})}$ & -29.17 & -28.87 & -32.75 & -35.08 & -32.94 & -36.27 & 1.98 & $\mathrm{~ns}$ \\
\hline $\mathrm{ED}_{2(\mathrm{k}=0.05 / \mathrm{h})}$ & -29.50 & -29.12 & -32.95 & -36.01 & -33.20 & -36.43 & 1.94 & $\mathrm{~ns}$ \\
\hline
\end{tabular}

ME, metabolizable energy; ED, effective degradability; DM, dry matter; NDF, neutral detergent fiber; SEM, standard error of mean; ns, Non significant.

Table 4 Prediction of some parameter of pasture by using multiple regresion

\begin{tabular}{|c|c|c|c|}
\hline Equations & Significance & $\mathrm{R}^{2}$ & RMSE \\
\hline Forage yield $(\mathrm{kg} / \mathrm{ha})=5846.048+5.946 \mathrm{~N}$ & $*$ & 0.248 & 937 \\
\hline Forage yield $(\mathrm{kg} / \mathrm{ha})=5514,679+15,887 \mathrm{~N}-0,04 \mathrm{~N}^{2}$ & $*$ & 0.215 & 928 \\
\hline $\mathrm{ADF}=48.871-13.178 \mathrm{GR}$ & $* *$ & 0.457 & 1.37 \\
\hline $\mathrm{ADF}=35.693+13.178 \mathrm{LR}$ & $* *$ & 0.457 & 1.37 \\
\hline $\left.\mathrm{ED}_{(\mathrm{NDF} \operatorname{deg} 48 \mathrm{~h}}\right)=41.122+0.233 \mathrm{~N}$ & $*$ & 0.220 & 3.98 \\
\hline $\mathrm{ED}_{(\mathrm{NDF} \operatorname{deg} 48 \mathrm{~h})}=42.983-0.032 \mathrm{~N}+0.0002 \mathrm{~N}^{2}$ & $*$ & 0.328 & 3.81 \\
\hline
\end{tabular}

$\mathrm{N}$, nitrogen; $\mathrm{ADF}$, acid detergent fiber; $\mathrm{ED}$, effective degradability; LR: Legume rate, GR: grass rate; $(\mathrm{P}<0.05)$, ** $(\mathrm{P}<0.01)$; RMSE, root mean square error

\section{Discussion}

\section{Botanical Composition}

Nitrogen fertilizer increased grass ratio approximately $55.8 \%$ and decreased legume ratio of clover-grass pasture approximately $22.4 \%$. It is reported that this reaction of $\mathrm{N}$ fertilizer depended on grass species of pasture (Peyraud et al., 1998; Mosquera et al., 2004). Wilman and Fisher (1996) reported that $\mathrm{N}$ fertilizer response of grass-clover mixed swards was lower than pure graminaeus swards due to the sensitivity of clover to nitrogen fertilizer. Because high nitrogen application negatively affects nodulation (Silva et al., 1993; Yolcu et al 2010) and symbiotic fixation (Fan et al., 2006) in legumes, the findings of this study about botanical composition were similar this results. Increasing $\mathrm{N}$ doses increased forage yield, on the other hand, were not significant statistically. Mosquero et al. (2004) reported that using $30 \mathrm{~kg} \mathrm{~N} \mathrm{ha}^{-1}$ fertilizer increased annual forage yield from pasture in the first year, followed by a decline in the second and third years and no response in the fourth year.

\section{Chemical Composition}

Nitrogen fertilizer influenced the dry matter content of pasture. $100 \mathrm{~kg} \mathrm{~N} /$ ha fertilizer increased approximately $2.21 \%$ the dry matter content of clover-grass pasture. Mosquero et al. (2004) pointed out that fertilizer increased DM content of grass-clover mixed swards in the first and fourth year. Similiar results have been reported by Salalün et al. (1999) for rye grass, Hatipoglu et al. (2001) for clover-grass pasture, Budakli et al. (2012) for barley and hairy vetch. NDF content of grass was not markedly influenced by different amounts of nitrogen fertilizer. In the present study, the findings concur with Valk et al. (1996) and Salaün et al. (1999).

Acid detergent fiber (ADF) concentration of native clover-grass pasture was decreased $t$ al. (1996) found that ADF content of pasture with $150 \mathrm{~N}$ fertilizer treatments was higher tsignificantly approximately $7.76 \%$ with increasing $\mathrm{N}$ fertilizer from 0 to $250 \mathrm{~kg}$ ha. These findings are agreement with the results of Zhang et al. (1995) for rye grass. In addition, Valk ehan of $450 \mathrm{~N}$ grass in the two periods. Besides, Hassan et al (2015) reported that the acid detergent fiber content of Panicum maximum was significantly influenced by nitrogen fertilization and increased nitrogen application significantly decreased ADF content. Moreover, Belanger et al. (1998) expressed that $\mathrm{N}$ deficiency would increase lignification. Hatipoğlu et al. (2001) reported that when the average environmental temperature at the time of growth stage of the plants was lower than the average temperature of that region and the rain falls more. The rate of pasture lignin was lower. However, same researchers found that $\mathrm{N}$ fertilizer had little effect on crude fiber or ADF of pasture (Peyraud et al., 1998). In contrast, some researchers found that $\mathrm{N}$ fertilizer increased ADF content of timothy (Messman et al., 1992), mileno grass (Campos et al., 2013), forage rape (Islam et al., 2012). $\mathrm{NEL}_{(\mathrm{Mcal} / \mathrm{kg})}$ content of pasture increased up to $8.3 \%$ by increasing amount of nitrogen application. NEL content depends on ADF concentration of pasture. 


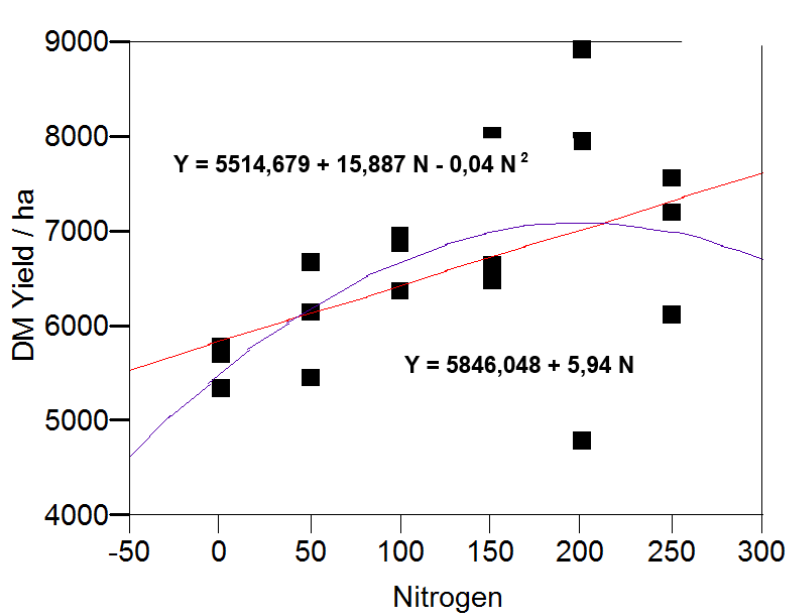

Figure 1 Relationships between nitrogen fertilizer and dry matter yield of pasture

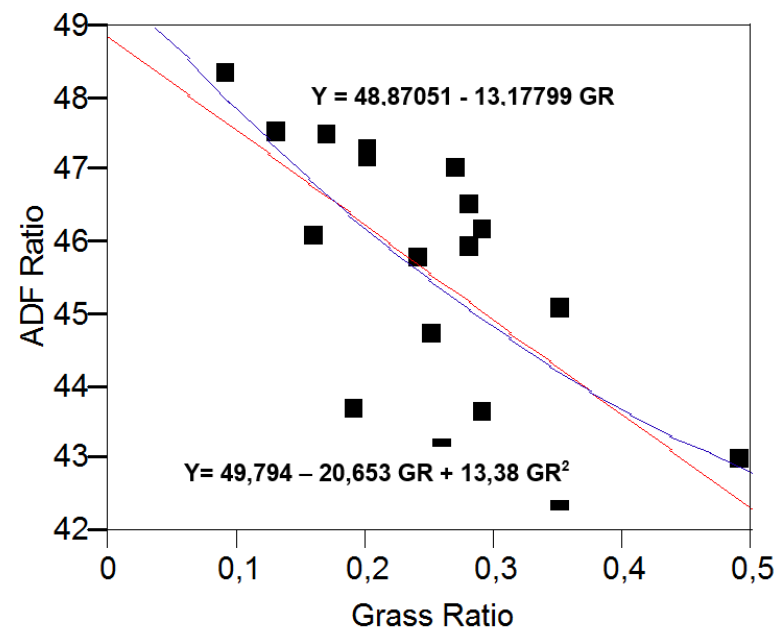

Figure 2 Relationships between acid detergent fiber content and grass ratio

Ash co of clover-grass sward increased up to $4.3 \%$ by increasing the level of nitrogen from 0 to 250 , except on $50 \mathrm{~kg} / \mathrm{ha}$ nitrogen doses. In the present study, this result is agreement with the findings of Hunt (1973). Onyeonagu et al. (2012) showed that increasing $\mathrm{N}$ fertilizer resulted in high uptake of nitrogen and potassium (K) from plant root and with perennial ryegrass, raising the level of nitrogen fertilizer from 59 to $111 \mathrm{~kg} / \mathrm{ha}$ significantly increased $\mathrm{K}$, $\mathrm{P}, \mathrm{Ca}, \mathrm{Mg}$ and $\mathrm{Na}$ minerals in dry matter. Linear and quadratic regression indicated a significant relationship between $\mathrm{N}$ fertilizer rate and forage DM yield for clover grass mixture. Similar findings results were reported by Dong et al. (2005) for perennial grass mixture. Besides, Malhi et al. (1986) reported that annual fertilizer $\mathrm{N}$ applications sustained more dry matter production than single $\mathrm{N}$ applications for bromegrass. In present study, relationship between ADF content of mixture sward and grass ratio was showed in Figure 2. Acid detergent fiber content of pasture was decreased linearly by using different $\mathrm{N}$ levels on pasture field. These results concur with the findings of Valk et al. (1996) for Lolium perenne.

\section{In Situ Degradability}

In the present study, DM and NDF degradability were not affected by using $\mathrm{N}$ fertilizer. Similar findings were stated by Reid et al. (1966) for Orchardgrass, Van
Vuuren et al. (1991) for perennial rye grass, Messman et al. (1992) for brome grass, Dong et al. (2005) for perenniel grass mixtures. In contrast, Calder and Mcleod (1968) reported that nitrogen applying in amounts of 52 and $103 \mathrm{~kg} / \mathrm{ha}$ to permanent pasture resulted in a decrease of digestibility by 2.15 and $2.23 \%$, respectively. Conversely, Valk et al. (1996) reported that higher degradation rate of cell walls with increased levels of $\mathrm{N}$ fertilization. There are a lot of different results about cell wall degradability. Viken and Volden (2009) expressed that NDF degradation characteristics are probably caused by interaction between $\mathrm{N}$ fertilization and climatic factors like temperature and water availability. Applied $\mathrm{N}$ fertilizer on pasture increased effective degradability of NDF in the 48-h degradation period. Similar results were pointed out by Valk et al. (1996) who found that the degradation rate of potentially degradable NDF was significantly increased at higher $\mathrm{N}$ application levels.

In conclusion, it was observed that applied $150 \mathrm{~kg} / \mathrm{ha}$ of nitrogen increased NEL content by $8.3 \%$ and dry matter by $13 \%$ of pasture. Even if not statistically significant, the forage yield of pasture has increased by $28 \%$. It is thought that more pasture management studies should be done in order to get more benefit from pasture in Turkey. In addition to, legumes cause bloating when freshly consumed by ruminant. During the spring period, the bloating losses are increased in the grazing animals. In the legume dominant native pasture, Decrease of the legume ratio by the increase of applied nitrogen doses can reduce animal losses.

\section{Acknowledgements}

This study is financially supported by the Republic of Turkey Ministry of Food, Agriculture and Livestock. We express sincerest gratitude to them for their support. In addition to, the authors would like to thank workers of East Mediterranen Agricultural Research Institute for helping during the study.

\section{References}

Acikgoz E. 2001. Forage Crops. University of Uludag, Publication No. 182. Bursa, Turkey, PP. 584

AOAC 1990. Official method of analysis. 15th ed., Association of Official Analytical Chemist, Washington, DC. USA.

Arvas Ö, Çelebi SZ, Y1lmaz İH. 2011. The effect of sewage sludge and chemical fertilizer on natural pasture's yield and botanical composition. J. Food Agric. Envir., 9: 525-530.

Bleanger G, McQueen RE. 1998. Analysis of nutritive value of timothy grown with varying $\mathrm{N}$ nutrition. Grass Forage Sci., 53: 109-119.

Calder FW, Leod M. 1968. In vitro digestibility of forage species as affected by fertiliser application stage of developmentand harvest dates. Can. J. Sci., 48: 17-24.

Carver LA, Barth KM, McLam JB, Fribourg HA, Connell JT, Bryan JM. 1975. Nutritive value of midland Bermuda pastures. J. Anim. Sci., 40: 183.

Campos FP, Sarmentoa P, Nussiob LG, Lugãoc SMB, Limad CG, Daniel JLP. 2013. Fiber monosaccharides and digestibility of milenio grass under $\mathrm{N}$ fertilization. Animal Feed Science and Technology 183: 17-21

Dong SK, Yang ZF, Long RJ, Hu ZZ, Kang MY. 2005. Effect of N fertilizer on the productivity and nutritive values of perennial grass mixtures in the alpine region of Qinghai-Tibetan Plateau, China. Can. J. Plant Sci., 85: 361-368. 
Fan FL, Zhang FS, Song YN, Sun JH, Bao XG, Guo TW, Li L. 2006. Nitrogen fixationof faba bean (Vicia faba L.) interacting with anon-legume in two contrasting intercropping systems. Plant and Soil, 283: 275-286.

Hassan A, Zewdu T, Urge M, Fikru S. 2015. Effect of nitrogen fertilizer application on nutritive value of cenchrus ciliaris and panicum maximum grown under irrigation at Gode, Somali Region. J Nutr Food Sci. 11: 5.

Hatipoğlu R, Avcı M, Kılıçalp N, Tükel T, Kökten K, Çınar S. 2001. Çukurova bölgesindeki bir merada fosforlu gübreleme ve farklı azot dozlarının ot verimi ve kalitesi ile botanik kompozisyona etkileri üzerine bir araştırma. Türkiye 4. Tarla Bitkileri Kongresi, Tekirdağ,

Hunt IV. 1973. Studies of response to fertilizer. Part 4. Effects of fertilizer nitrogen on the chemical composition of primary growth of perennial ryegrass. J. Grassland Soc., 28: 171-180.

Islam MR, Carcia SC, Horadagoda A. 2012. Effects of residiual nitrogen, nitrogen fertilizer, sowing date and harvest time on yield and nutritive value of forage rape. Anim. Feed Sci. and Tech., 177: 52-64.

Jung HG, Allen MS. 1995. Characteristics of plant cell walls affecting intake and digestibility of forage by ruminants. J. Anim. Sci., 73: 2774-2790.

Khan RI, Alam MR, Amin MR. 1999. Effect of season and fertilizer on species compozition and nutritive value of native grasses. Asian-Aus. J. Anim. Sci., 12: 1222-1227.

Lai N V, Thu Huong N T. 1999. Comparison of the in-sacco rumen and washing loss methods to estimate the potential energetic value for livestock of leaves from tropical trees, shrubs and crop residues. Livestock Res. for Rural Develop., 11: 1-6.

Malhi SS, McBeath DK. Baron VS. 1986. Effects of nitrogen application on yield and quality of bromegrass hay in central Alberta. Can. J. Plant Sci., 66: 609-616.

Messman MA, Weisst WPJ, Erickson D. 1992. Effects of Nitrogen Fertilization and Maturity of Bromegrass on Nitrogen and Amino Acid Utilization by Cows. J. Anim. Sci., 70: 566-575.

Mosquero MR, Rodruguez AG, Rodruguez AR. 2004. Fertilization with nitrogen and potassium on pastures in temperate areas. $\mathrm{J}$. of Range Manag., 75: 280-290.

NRC 2001. Nutrient requirements of dairy cattle. $7^{\text {th }}$ rev.ed. National Academy Press, Washington, DC.

Onyeonagu CC, Anyadiegwu OA, Uwalaka TK. 2012. The quality of crop fractions of a degraded Panicum maximum pasture under different cutting intervals and nitrogen fertilizer rates. African J. Agric. Res., 7: 2174-2182.

Ørskov ER, McDonald I. 1979. The estimation of protein degradability in the rumen from incubation measurements weighed according to rate of passage. J. Agric. Sci. (Camb.), 92: 499- 503.

Peyraud JL, Astigarraga L. 1998. Review of the effect of nitrogen fertilization on the chemical composition, intake, digestion and nutritive value of fresh herbage: consequences on animal nutrition and $\mathrm{N}$ balance. Anim. Feed Sci. and Tech., 72: 235259 .
Reid RL, Jung CA, Murray SJ. 1966. Nitrogen fertilazition in relation to the palability and nutritive value of orchardgrass. J. Anim. Sci., 25: 636-645.

Salaüna C, Straalen M, Van Wilfried KJ, Peyraud JL, Vuurena AMV. 1999. In situ degradation of perennial rye grass from grazed pastures during the season at two levels of nitrogen fertilization. Annales de zootechnie, 48: 35-46.

Silva PMD, Tsai SM, Bonetti M. 1993. Response to inoculation and $\mathrm{N}$ fertilization for increased yield and biological nitrogen fixation of common bean (Phaseolus vulgaris L.). Plant and Soil, 152: 123-130.

SPSS 2007. Survival Manual A Step by Step Guide to Data Analysis Using SPSS, 4th Edition Spiral-Bound.

Valk H, Kappers IE, Tamminga S. 1996. In sacco degradation characteristics of organic matter, neutral detergent fibre and crude protein of fresh grass fertilized with different amounts of nitrogen. Anim. Feed Sci. and Tech., 63: 63-87.

Valk H, Leusink-Kappers IE, Van vuren AM. 2000. Effect of reducing nitrogen fertilizer on grassland on grass intake, digestibility and milk production of dairy cows. Livestock Prod. Sci., 63: 27-28.

Van Soest PJ, Robertson JB, Lewis BA. 1991. Methods for dietary fiber, neutral detergent fiber and non-starch polysaccharides in relation to animal nutrition. J. Dairy Sci., 74: 3583- 3597.

Van Vuuren AM, Tamminga, S, Ketelaar RS. 1991. In sacco degradation of organic matter and crude protein of fres gerass (Lolium perenne) in the Rumen of grazing dairy cows. J. Agric. Sci., 116: 429.

Viken HN, Voldenb H. 2009. Effect of maturity stage, nitrogen fertilization and seasonal variation on ruminal degradation characteristics of neutral detergent fibre in timothy (Phleum pratense L.). Anim. Feed Sci. and Tech., 149: 30-59.

Wilman D, Fisher A. 1996. Effects of interval between harvests and application of fertiliser $\mathrm{N}$ in spring on the growth of perennial rye grass in a grass/ white clover sward. Grass Forage Sci., 51: 52-57.

Yolcu H, Serin Y, Tan M. 2010. The effects of seeding patterns, nitrogen and phosphorus fertilizations on production and botanical composition in lucerne-smooth bromegrass mixtures. Bulg. J. Agric. Sci., 16: 719-727.

Zhang Y, Bunting LD, Kappep LC, Hafley JL. 1995. Influence of nitrogen fertilization and defoliation frequency on nitrogen constituents and feeding value of annual ryegrass. J. Anim. Sci., 73: 2474-2482.

Zimmerman I. 1980. Factors influencing the feed intake and live weight change of beef cattle on beef cattle on a mixed tree savannah in the Transvaal. J. Range Manage, 33: 132-136. 